\title{
Technological properties of porous concrete autoclave and non-autoclave hardening
}

\author{
O.M. Nedbailo (0000-0003-1416-9651), O.G. Chernyshyn (0000-0001-7702-894X) \\ The State Enterprise "Engineering Center "Drying”, Institute of Engineering Thermophysics of NAS of Ukraine, \\ str. Bulakhovskogo, 2, Bldg. 2, Kyiv, 03164, Ukraine \\ Tel.: +380444240279, tel./fax +380444243283 \\ E-mail: icsushka@gmail.com
}

Article info: received 17.09.2020, revised 28.09.2020, accepted 30.09.2020

Nedbailo, O.M., Chernyshyn, O.G. (2020) Technological properties of porous concrete autoclave and non-autoclave hardening 3(48), doi: 10.26909/csl.3.2020.4

Some aspects of resource saving problem in the process of construction of heated construction installations are considered in the paper, also heat transfer problem in porous concrete. Is paid attention to necessity of application with mass construction of habitation of products from porous concrete, first of all - products from of cellular concrete.

In article the basic requirements of the standard documents regulating constructive properties of various building materials, including various concrete are analyzed.

The design a warm wall on the basis of products from porous concrete is considered. Its advantages in comparison with known designs of warm walls are shown.

In article changes of technological properties of various building materials are considered at influence on them of a moisture. The analysis of the standard-regulating documents, concerning operational qualities, concerning reliability and durability of designs is carried out.

The basic technical properties gas-concrete non-autoclave solidification on the basis of a waste stone machining are analyzed. Results of researches technology indicators cement cellular concrete non-autoclave solidification with offered filling material are resulted.

Key words: porous concrete autoclave, gas-concrete non-autoclave solidification.

\section{Технологічні властивості пористого бетону автоклавного та неавтоклавного твердіння}

\author{
О.М. Недбайло, О.Г. Чернишин
}

Державне підприємство «Інженерний ичентр «Сушка»» Інституту технічної теплофізики НАН України, Київ, Україна

У статті розглянуті деякі аспекти проблеми економії ресурсів у процесі будівництва опалювальних будівельних установок, а також проблему теплопровідності в пористому бетоні. Звертається увага на необхідність застосування при масовому будівництві житла виробів з пористого бетону.

Проаналізовані основні вимоги типових документів, що регулюють технологічні властивості різних будівельних матеріалів, включаючи різні бетони. Розглядається конструкція теплої стіни на основі виробів 3 пористого бетону. Показані його переваги в порівнянні з відомими конструкціями теплих стін.

В роботі розглядаються зміни технологічних властивостей різних будівельних матеріалів при впливі на них вологи. Проведений аналіз нормативно-правових документів, що стосуються експлуатаційних якостей, щодо надійності та довговічності конструкцій.

Проаналізовані основні технологічні властивості газобетону неавтоклавного твердіння на основі механічного оброблення відходів. Наведені результати досліджень технологічних показників пористих бетонів автоклавного та неавтоклавного твердіння. 


\section{Умовні позначення та скорочення}

ГАТ - газобетон автоклавного твердіння; РФ - рідка фаза; КМО - комплект мобільного обладнання; МЗ - мікрозаповнювач; КР - коефіцієнт розм'ягчення; ЦГБ - цементний газобетон; ЦПБ - цементний пінобетон.

\section{Вступ}

Один 3 логістичних напрямків в області практичного енергозбереження пов'язаний із масовим застосуванням виробів 3 пористих композиційних матеріалів, зокрема - пористих бетонів. Пористі бетони - необпалювані (з температурою структуроутворення $T<573$ К), тверді композиційні матеріали із загальною пористістю не менше $50 \%$.

Пористі бетони застосовують в: енергоефективному, наприклад, житловому будівництві із заданим рівнем опору теплопередачі огороджувальних конструкцій $R_{\mathrm{T}}[1]$; будівництві зі зменшеною матеріаломісткістю; теплових агрегатах.

До пористих відносять бетони на основі, як правило, мінеральних в'яжучих речовин, що містять газоповітряні (газобетони) або піноповітряні (пінобетони) пори. Визначення показників пористих бетонів наведені також в роботах $[2,3]$.

Мета роботи полягає у аналізі технологічних властивостей пористого бетону автоклавного та неавтоклавного твердіння та їхній систематизації.

\section{Матеріали та методи дослідження}

Як правило, практичними технологами, під макроструктурою розуміється система будови пористого бетону із розподілом пір за розмірами, що візуально оцінюється. Пори в бетонах можна класифікувати, наприклад, за розмірами (таблиця 1).

До огороджувальних конструкцій, наприклад, стінових i, відповідно, пористих бетонів висувається комплекс технічних і теплофізичних вимог. Найбільш важливими є такі критерії: міцність при різних видах деформацій, середня щільність у су-

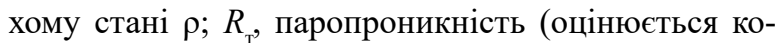

ефіцієнтом паропроникності $F$; за європейським стандартом ЕН771-4-2003 «Вимоги до будівельних блоків 3 автоклавного ніздрюватого бетону» регламентується і коефіцієнт дифузії водяної пари), експлуатаційна вологість $W_{\mathrm{e}}$, сорбційна вологість $W_{\mathrm{c}}$, морозостійкість М, ступінь ізотропності (характеризується ненормативним коефіцієнтом анізотропії $A_{\mathrm{j}}$ ) і ступінь однорідності (характеризується ненормативним коефіцієнтом однорідності $D_{\mathrm{i}}$ ) параметрів якості, усадка (карбонізаційна і при висиханні $U$ ), теплопровідність $\lambda$, коефіцієнт розм'якшення КР, звукоізоляція, звукопоглинання, набухання, повзучість, повітропроникність, вогнестійкість.

До умовної групи «бетони автоклавного твердіння» можуть бути віднесені бетони, довговічна мікро(нано)структура яких формується тільки в процесі синтезу мінеральних новоутворень при підвищених тиску і температури в апаратах - автоклавах (посудинах, що працюють під тиском 1,0 - 1,4 МПа). Відзначимо, що термін «довговічність» вимагає визначення і конкретизації (в т.ч. в документації $€$ тільки один стандартизований параметр довговічності - морозостійкість).

Не всі істотно значимі параметри якості нормовані в стандартах на бетони та вироби. Виготовлення пористих бетонів 3 необхідними фізико-технічними властивостями можливе при здійсненні промислових технологічних процесів, що включають хімічні та/або силові дії на сировинні матеріали та/або формувальні суміші, що призводять до отримання дисперсних систем 3 необхідною хімічною активністю. Обов'язкова активація сировинних компонентів сприяє формуванню мікро(нано)структури пористих бетонів, що характеризується підвищеними міцністю при стисканні $R, \mathrm{M}, D_{\mathrm{i}}$, ступенем ізотропності, зменшеними $W_{c}, \lambda$ i $U[1,4$ - 7].

Таблиця 1.

Орієнтовна класифікація пір в бетонах

\begin{tabular}{|c|c|c|}
\hline Різновид пір & Розмір пір $d$, мкм & Походження пір (приблизні методи дослідження) \\
\hline Мікро(нано)пори & $<0,1$ & $\begin{array}{c}\text { Контракційні, капілярні пори } \\
\text { (адсорбційні методи, ртутна порометрія) }\end{array}$ \\
\hline Мезопори & $0,1-100$ & $\begin{array}{c}\text { Перехідні (проміжні) пори: контракційні, капілярні } \\
\text { (адсорбційні методи, ртутна, гідравлічна порометрії) }\end{array}$ \\
\hline Макропори & $>100$ & $\begin{array}{c}\text { Газо-, піно-, газопінопори, повітряні пори } \\
\text { (мікроскопічний аналіз, візуальна оцінка) }\end{array}$ \\
\hline
\end{tabular}


В країнах близького закордону вироби з пористих бетонів виготовляють, в основному, за різальною (т.зв. «струнною») технологією у вигляді збірних неармованих малорозмірних блоків з газобетону автоклавного твердіння (СТБ 1117-98 «Блоки 3 ніздрюватих бетонів стінові. Технічні умови», ГОСТ 21520-89); в європейській науково-технічній літеpaтурі - Autoclaved Aerated Concrete (AАC). Якісні пористі бетони мають прийнятне для будівельників співвідношення між параметрами $\rho$ і $R$.

Блоки (монтажні елементи) можуть бути: призматичної форми, 3 пазогребінною конструкцією стиків, з отворами («кишенями») для захоплення, зі шпонками [8].

Сучасні технічні вимоги до виробів з ААС викладені в СТБ ЕН771-4 «Вимоги до будівельних блоків. Будівельні блоки з автоклавного ніздрюватого бетону», DIN4165 «Газосилікатні блоки і плоскі камені», DIN EN771-4 «Положення по будівельній цеглі. Блоки з пористого бетону » [8].

У технологіях виробництва бетонів автоклавного і неавтоклавного твердіння реалізовані різні принципи структуроутворення, тому ці бетони мають відмінні властивості. При цьому, якщо у газобетонів автоклавного твердіння (ГАТ) процес твердіння закінчується після закінчення автоклавування, то, наприклад, в цементних газобетонах (ЦГБ) або цементних пінобетонах (ЦПБ) процес твердіння i набуття міцності носить довготривалий характер (практично до 2 років). Однак в цей період в умовах напруженого стану («передчасне» навантаження конструкцій) в ЦГБ і ЦПБ мають місце і деструктивні процеси.

Природа адгезійного зв'язку між цементуючою матрицею і мікрозаповнювачем (М3) у ГАТ, ЦГБ і ЦПБ різна [1]. У ЦГБ і ЦПБ можливе застосування в якості М3 не тільки меленого кварцового піску, а й інших гірських порід і техногенних продуктів (шлаки, відходи каменевидобування і т.д.).

Технології виробництва виробів 3 пористих бетонів автоклавного і неавтоклавного твердіння напрямки, що інтенсивно розвиваються. Діють, наприклад, стандарти ДСТУ Б В.2.7-45-96 «Бетони ніздрюваті, СТБ 1117-98 «Блоки $з$ ніздрюватих бетонів стінові» та ін., в яких викладені вимоги до ніздрюватих бетонів автоклавного (в основному до ГАТ-ААС) і неавтоклавного (в основному - ЦГБ і ЦПБ) твердіння і виробам з них.

В Україні, що практично не має в т.ч. промислового виробництва виробів з пористих бетонів, стрімко розвиваються непромислові способи виробництва виробів з ЦГБ і ЦПБ з незадовільними будівельно-технічними властивостями (застосовується обладнання, що має технічний рівень, що не піддається оцінюванню).
Внаслідок дефіциту якісних виробів з ГАТ ці ж неперспективні способи отримують розвиток і в Росії. Створено ряд машин і механізмів у вигляді комплектів мобільного обладнання (КМО) з річною продуктивністю до 40 тис. неармованих стінових блоків [1]. Очевидно, що серед пористих бетонів масового виробництва альтернативи ГАТ, як якісним стіновим і теплоізоляційним матеріалами немає i, в найближчому майбутньому, виходячи з досягнутого рівня світових знань в області пористих бетонів, не передбачається.

\section{Результати та їх обговорення}

В останні роки виконаний ряд теоретичних і експериментальних досліджень, в яких запропоновані загальні якісні моделі міцності, теплопровідності і усадки пористих бетонів, розроблені технічні рішення збірних перегородок і теплих стін, а також отримали подальший розвиток технологічні прийоми по виробництву неавтоклавних цементних ніздрюватих бетонів з покращеними фізико технічними властивостями $[1,4]$. Показано, що можливе отримання ЦПБ з задовільними будівельно-технічними властивостями, зокрема - усадкою при висиханні.

Усадка як фізико-хімічний процес полягає в тому, що деформація цементуючою матриці відбувається не внаслідок наявності зовнішнього силового впливу, а є результатом досить тривалих процесів перетворення клінкерних фаз в кристалогідратні з'єднання в середовищі з певним газовим складом. Усадка супроводжується масообміном (зменшенням вмісту РФ) і загальної структурною перебудовою, глибина якої залежить від ступеня завершеності мікро(нано) структуроутворення штучного каменю [1].

Відомо, що ГАТ автоклавного походження, внаслідок практичної відсутності гелеподібної складової, схильні до усадки і набухання в меншій мірі, ніж ЦГБ - продукти гідратації мінералів клінкеру (має місце $U \rightarrow U_{\min }$ ) [1 - 3]. Причиною підвищеної усадки бетонів неавтоклавного тверднення (ЦГБ і ЦПБ) $€$ наявність підвищеної кількості аморфної колоїдної фази цементного каменю. Автоклавне оброблення сирцю перетворює таку фазу в кристалічну [3].

Процес усадки є руйнівним (в критичній ситуації $\left(U>U_{\text {кр }}\right)$. При цьому утворюються усадочні тріщини, що призводять до втрати бетоном несучої здатності в будівельних виробах певних критичних розмірів $N$.

У загальному випадку можна записати $[1,6]$

$$
U=\varphi\left(\rho, n, N, C, L, D_{\mathrm{i}}, A_{\mathrm{u}}\right),
$$

де $n$ - об'ємна доля цементуючої речовини; $L-$ умовні параметри середовища експлуатації виробів; 
$D_{\mathrm{i}}, A_{\mathrm{u}}-$ коефіцієнти однорідності мікроструктури і анізотропії усадки (параметри якості суміші і бетону).

Теорія поверхневих сил в т.ч. не дозволяє робити точні розрахунки значень $U$ і параметрів набухання виробів з пористих бетонів [1]. Не розроблена і методика розрахунку значень $N=N_{\min }$. Для забезпечення усадки $U \leq U_{\text {кр }}$ необхідно насамперед при заданому значенні $\rho$ зменшити, наприклад, в ЦГБ або ЦПБ кількість негідратованих частинок цементу. При $n \rightarrow n_{\min }$ матиме місце не тільки підвищення $R$ бетону, але і зменшення швидкості процесу усадки, що, в загальному випадку, залежить перш за все від факторів $\rho$, і $L$, і має найбільше значення у теплоізоляційних виробів.

Швидкість процесу усадки істотно залежить і від температури середовища експлуатації. Зменшення контракції можливо, якщо в процесі виробництва, наприклад, цементовмісних бетонів буде забезпечена висока якість суміші завдяки фізико-хімічній активації сировини [1, 4 - 8]. Крім усадки при висиханні має місце і недостатньо вивчена карбонізована усадка пористих бетонів (практично - карбонізаційне набухання).

У таблиці 2 наведені приблизні дані про властивості пористих бетонів автоклавного і неавтоклав-

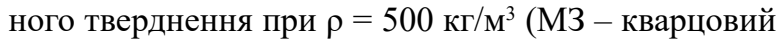
пісок, активований в кульовому млині). Слід зазначити, що криві повзучості ЦГБ і ЦПБ при різних напружених станах бетону в діапазоні температур $233 \mathrm{~K}<T<313$ К практично не встановлені.

Номенклатура і області застосування виробів 3 ГАТ значно ширші, ніж у виробів з ЦГБ і ЦПБ, що можна застосовувати в енергоефективному та господарському будівництві з деякими відомими обмеженнями $[1,4$ - 6].

При виготовленні продукції з ГАТ використовують комплекти обладнання, що дозволяють отримувати якісні збірні вироби з необхідними фізико-технічними властивостями. Разом з тим, на цьому ж обладнанні можливе отримання збірних виробів, наприклад, стінових блоків і з цементного пористого бетону неавтоклавного твердіння (деякі європейські фірми виробляють ГАТ без застосування вапна).

Наразі в Україні в Київському національному університеті будівництва та архітектури виконуються науково-практичні роботи, кінцевою метою яких $\epsilon$ приведення існуючої нормативно-регуляторної документації у відповідність до основних положень гармонізованих стандартів Свросоюзу EN 771-4: 2003 і EN +1745: 2002 (Е), що діють в країнах, що входять в Європейську асоціацію виробників автоклавного ніздрюватого бетону (The European Autoclaved Aerated Concrete Association) [8]. Найбільш розвинену нормативну базу і високий технічний рівень виробництва виробів з ГАТ має Республіка Бєларусь.

Виходячи з відмінностей у фізико-технічних характеристиках (таблиці 2 і 3) і областей ефективного застосування доцільним є створення розвиненої незалежної (роздільної) нормативної бази для організації виробництва виробів з автоклавних і неавтоклавних пористих бетонів.

При оцінюванні якості пористих бетонів визначення марки за міцністю допустимо проводити не тільки шляхом випробування зразків бетону, але і шляхом випробування кінцевої продукції: блоків, плит (наприклад, стінових блоків і теплоізоляційних плит

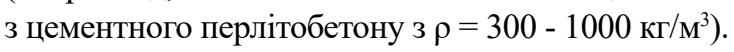

3 огляду на функціональне призначення виробів 3 пористих бетонів, основним параметром якості слід вважати $\rho$, тому що цей показник в цілому корелює з теплопровідністю бетону. Прагнення щодо досягнення заданої міцності, як основного параметра якості, може призвести до зменшення обсягів виробництва виробів з бетонів $3 \rho<500$ кг/м ${ }^{3}$. За проектні параметри пористого бетону доцільно приймати: $R=R_{\min }, \rho=\rho_{\min }, U=U_{\max }$.

\section{Висновки}

1. Пористі бетони володіють такими фізико-технічними і теплофізичними властивостями, що дозволяють прогнозувати розвиток номенклатури армованих і неармованих збірних виробів і зростання обсягів їх використання в індустріальному будівництві. Якісні пористі бетони неавтоклавного твердіння при раціональному індустріальному їх виробництві та цільове використання можуть, як і ГАТ, вирішувати завдання в області енергоресурсозбереження в будівництві $[10,11]$.

2. Нормативна база для виробництва пористих бетонів автоклавного і неавтоклавного твердіння, а також відповідних армованих і неармованих виробів повинна бути незалежною (роздільної, окремою) і сприяти розвитку різальної (струнної) технологї̈.

3. 3 метою виключення дискредитації пористого бетону слід регламентувати його щільність $\left(\rho>1400 \kappa г / \mathrm{M}^{3}\right)$ для влаштування одношарових перегородок (внутрішніх стін) товщиною 80 - 100 мм. Морозостійкість, теплопровідність і паропроникність пористого бетону для влаштування внутрішніх стін і перегородок енергоефективних (опалювальних) об'єктів не слід нормувати.

4. Кінцева мета аналізу матеріалів статті полягає в пошуках шляхів зменшення енерговитрат в сфері виробництва при забезпеченні задовільної якості (за параметрами зовнішнього вигляду і відтворюваності (точності) розмірів) виробів, в тому числі, з ГАТ, 
Таблиця 2.

Порівняльні властивості пористих бетонів автоклавного і неавтоклавного твердіння при $\rho=500$ кг/м³

\begin{tabular}{|c|c|c|c|c|}
\hline \multirow[b]{2}{*}{ Параметри якості } & \multicolumn{3}{|c|}{ Значення параметрів (рангів - балів) в бетонах } & \multirow{2}{*}{$\begin{array}{c}\text { Наявність } \\
\text { стандартизованої } \\
\text { методики } \\
\text { випробування } \\
\text { (оцінки } \\
\text { параметра) }\end{array}$} \\
\hline & $\begin{array}{c}\text { Газобетони } \\
\text { автоклавного } \\
\text { твердіння на вап- } \\
\text { няно-цементному } \\
\text { в'яжучому }\end{array}$ & $\begin{array}{c}\text { Цементні } \\
\text { газобетони } \\
\text { неавтоклавного } \\
\text { твердіння }\end{array}$ & $\begin{array}{c}\text { Цементні } \\
\text { пінобетони } \\
\text { неавтоклавного } \\
\text { твердіння }\end{array}$ & \\
\hline $\begin{array}{l}\text { Міцність } \\
\text { при стисканні }\end{array}$ & 1,0 & 0,9 & 0,8 & $\epsilon$ \\
\hline $\begin{array}{l}\text { Розчинність бетону } \\
\text { в воді (вихід } \mathrm{CaO})\end{array}$ & водостійкий & водостійкий & не водостійкий & - \\
\hline Усадка при висиханні & 0,7 & 0,9 & 1,0 & $\epsilon$ \\
\hline Набухання & 0,8 & 0,9 & 1,0 & - \\
\hline $\begin{array}{l}\text { Повзучість при лінійно- } \\
\text { му напруженому стані } \\
(T=293 \text { К) }\end{array}$ & 0,8 & 0,9 & 1,0 & - \\
\hline $\begin{array}{l}\text { Однорідність щільності } \\
\text { бетону при висоті маси- } \\
\text { ву до } 600 \text { мм }\end{array}$ & 0,9 & 0,9 & 1,0 & - \\
\hline $\begin{array}{l}\text { Анізотропія міцності } \\
\text { і теплопровідності }\end{array}$ & 1,0 & 1,0 & 0,8 & - \\
\hline $\begin{array}{l}\text { Адгезія (зчеплення) } \\
\text { з захисно-декоративним } \\
\text { покриттям }\end{array}$ & 1,0 & 1,0 & 0,9 & - \\
\hline Сорбційна вологість & 1,0 & 1,0 & 0,9 & $\epsilon$ \\
\hline Морозостійкость & 1,0 & 0,9 & 0,8 & $\epsilon$ \\
\hline $\begin{array}{l}\text { Тривалість набирання } \\
\text { сирцем міцності перед } \\
\text { розрізанням масиву }\end{array}$ & 0,6 & 0,8 & 1,0 & $\epsilon$ \\
\hline $\begin{array}{l}\text { Твердіння } \\
\text { масиву-сирцю } \\
\text { у природних умовах }\end{array}$ & недопустимо & допустимо & допустимо & \\
\hline $\begin{array}{l}\text { Загальна енергоємність } \\
\text { технологічного процесу }\end{array}$ & 1,0 & 0,7 & 0,7 & \\
\hline
\end{tabular}

Примітки: 1. Вказані властивості пористих бетонів в неармованих виробах. 2. Дані порівняння про карбонізаційну усадку відсутні. 
Таблиця 3.

Результати експериментів щодо оцінювання розчинності в воді (переходу в рідку фазу) структуроутворюючих компонентів пористих бетонів

\begin{tabular}{|c|c|c|}
\hline Вид пористого бетону & Вік бетону & $\begin{array}{c}\text { pН рідкої фази через } 2 \text { години } \\
\text { після контакту бетону з водою } \\
(\mathrm{pH}=7)\end{array}$ \\
\hline 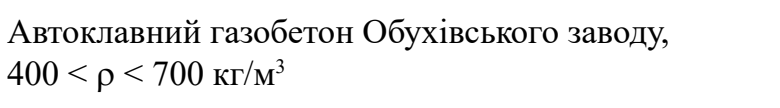 & $\begin{array}{c}1 \text { рік } \\
10 \text { років }\end{array}$ & $\begin{array}{l}7 \\
7\end{array}$ \\
\hline 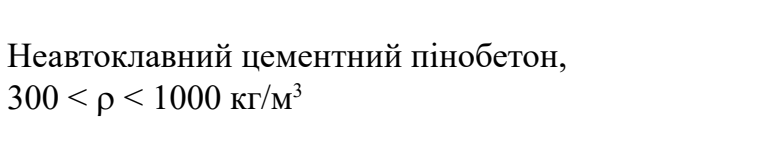 & $\begin{array}{l}2 \text { міс. } \\
1 \text { рік } \\
5 \text { років }\end{array}$ & $\begin{array}{l}12-13 \\
11-12 \\
11-12\end{array}$ \\
\hline $\begin{array}{l}\text { Неавтоклавний цементний пінобетон з додаванням } \\
\text { відходів виробництва спученого перлітового піску } \\
\text { (активна мінеральна домішка), } 500<\rho<800 \text { кг/м }\end{array}$ & $\begin{array}{l}2 \text { міс. } \\
1 \text { рік } \\
3 \text { роки }\end{array}$ & $\begin{array}{l}11-12 \\
11-12 \\
11-12\end{array}$ \\
\hline 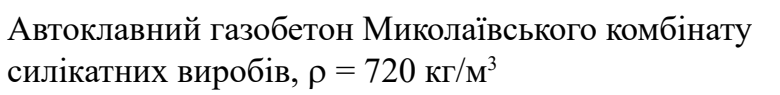 & 25 років & 7 \\
\hline
\end{tabular}

ЦГБ та ЦПБ. Інші параметри якості будуть залежати від виду застосованих сировинних матеріалів і способу тужавлення масиву - сирцю після розрізання (пропарювання, автоклавування при 0,1 - 0,2 МПа). Не виключено, що при приготуванні якісної сировинної суміші (вихідна суха, механоактивована цементно-піщана суміш, додатково активована в складі формувальної суміші) знайдуть застосування і нетрадиційні для газобетонних технологій способи активації сировини, засновані на розробленому в ІТТФ НАН України методі дискретно-імпульсного введення енергії (ДІВЕ).

5. Виробництво стінових, теплоізоляційних і перегородкових збірних виробів на основі ЦПБ з необхідним рівнем фізико-технічних властивостей може бути організовано за різальною технологією шляхом застосування уніфікованих КМО модульно-блокового виконання 3 продуктивністю до 50 тис. м $^{3} /$ рік (форми об'ємом до 2,0 м³, масив висотою не більше 900 мм, розрізання сирцю на піддоні, наявність підрізного шару і т. i.).

\section{References}

1. Опєкунов, В.В. Пористі композиційні матеріали та їх використання у будівництві. - К.: АБУ. 2006. $-85 \mathrm{c}$.

2. Сажнев, Н.П., Гончарик, В.Н., Гарнашевич, Г.С. Производство ячеистобетонных изделий. Теория и практика. - Мн.: Стринко. - 2004. - 384 с.

3. Горяйнов, К.Э., Горяйнова, С.К. Технология те- плоизоляционных материалов и изделий. - M: Стройиздат. - 1982. - 376 с.

4. Опекунов, В.В. Конструкционно-теплоизоляционные бетоны. - К.: Академпериодика. - 2002. - 270 с. 5. Опекунов, В.В., Лысов, В.П., Голубев, Н.М. Пористые бетоны и области их применения // Вестник Белорусского национального технического университета. - Минск: БНТУ. - 2005. - вып.1. C. $10-17$.

6. Опекунов, В.В. Эффективное применение пористых бетонов. - Строительные материалы. - 2005. №12, - C. 25 - 28.

7. Опекунов, В.В. Прочность, однородность и анизотропия свойств пористых бетонов. - Строительные материалы. - 2006. - №11. - С. 17 - 21.

8. Галкин, С.Л., Сажнев, Н.П., Соколовский, Л.В. Применение ячеистобетонных изделий. Теория и практика. - Мн.: Стринко. - 2006. - 448 с.

9. Опєкунов, B.B. Нормативна база та властивості пористих бетонів // Будівництво. Наука. Проекти. Економіка. - 2007. - № 41(8). - С. 41 - 44.

10. Патент № 26424 на корисну модель, Україна, В28С5/00. Обладнання для виготовлення виробів 3 ніздрюватого бетону неавтоклавного тужавлення / В.В. Опєкунов (Україна). - № u2007 02923; заявлено 20.03.07; опубл. 25.09.2007, Бюл. №15. - 2 с.

11. Паплавскис, Я.М. Создание нормативно-технической базы для применения ячеистобетонных изделий // Будівельні матеріали, вироби та санітарна техніка: Зб. наук. праць. - К.: НДІБМВ. - 2007. вып. 24. - С. 55 - 58. 